\title{
Understory species and functional diversity in a chronosequence of jack pine and red pine stands in the south-central boreal forest.
}

\begin{tabular}{|r|l|}
\hline Journal: & Botany \\
\hline Manuscript ID & cjb-2015-0159.R2 \\
\hline Manuscript Type: & Article \\
\hline Date Submitted by the Author: & 07-Dec-2015 \\
\hline Complete List of Authors: & $\begin{array}{l}\text { Park, Andrew; University of Winnipeg, Biology } \\
\text { Carpenter, Corey; University of Winnipeg }\end{array}$ \\
\hline Keyword: & $\begin{array}{l}\text { Taxonomic diversity, Functional diversity, red pine and jack pine, RLQ } \\
\text { analysis, Fourth corner }\end{array}$ \\
\hline \multicolumn{2}{|l}{} \\
\hline
\end{tabular}

SCHOLARONE ${ }^{\text {IH }}$

Manuscripts 
Understory species and functional diversity in a chronosequence of jack pine and red pine stands in the south-central boreal forest.

Andrew Park *

Biology Department and Centre for Forest Interdisciplinary Research (CFIR), University of Winnipeg

515 Portage Avenue,

Winnipeg, MB, R3B 2E9

a.park@uwinnipeg.ca

(204) 7869407

Corey Carpenter

Biology Department and Centre for Forest Interdisciplinary Research (CFIR), University of Winnipeg

515 Portage Avenue,

Winnipeg, MB, R3B 2E9

\section{* Corresponding author}

Running Head: Understory species and functional diversity in boreal pines 


\begin{abstract}
Dominant tree species and anthropogenic disturbances influence understory taxonomic diversity (TD) and species traits (Functional Diversity - FD) in managed forests. We compared understory TD and FD in managed jack pine (Pinus banksiana Lamb.) stands and red pine (Pinus resinosa Ait.) plantations. Understory herbs, grasses, shrubs and non-vascular species were assessed in $1 \mathrm{~m}^{2}$ quadrats on two perpendicular line transects. Data were analyzed using generalised least squares regression, and multivariate fourth corner and RLQ analyses. Although there were few differences in understory species communities, red pine plantations appeared to impose weak environmental filters on TD in ways that were absent in jack pine stands. Taxonomic diversity declined with age in red pine but not in jack pine, and may have been affected by the accumulation of litter cover in red pine stands. Although vegetation cover was lower in red pine than in jack pine, species richness on a percent cover basis was greater, and saturated at high cover levels in jack pine. Functional richness and evenness were unaffected by overstory species, but high litter cover favoured higher values of functional divergence. These results imply that there was a high level of functional redundancy among species for the suite of traits that we analyzed.
\end{abstract}

\title{
Keywords
}

Taxonomic diversity; Functional diversity; RLQ analysis; fourth corner; Generalized least squares; Red pine; Jack pine. 


\section{Introduction}

Although the world continues to support large areas of forest, the imprint of human activities is ubiquitous across forest biomes (Fonder 2007). Forestry, in particular, leads to far-reaching changes in the distribution of stand types in landscapes (Boucher et al. 2006), woody debris and standing dead trees (Brassard and Chen 2008; Sturtevant et al. 1997), and the distribution of biota (e.g. Niemelä 1997; Pettersson 1997; Ramovs and Roberts 2005). Even in relatively species-poor boreal forests, the qualitatively different impacts of forestry and natural disturbances lead to large differences in age class distribution (Boucher et al. 2006), dominant tree species (Aubin et al. 2014; Hearndon et al. 1992), and understory community composition (Aubin et al. 2014; Aubin et al. 2008; Hart and Chen 2006; Venier et al. 2014). In some cases, these differences can persist for decades across a successional sere (e.g Aubin et al. 2014; Ramovs and Roberts 2005), but for a counter-example see Reich et al. (2001).

Different types and degrees of anthropogenic disturbances differ in their effects on understory species richness and the species characteristics (or traits) that they favour or inhibit. Aubin et al (2014) point out that clearcut harvesting followed a year or two later by mechanical site preparation constitute a "double disturbance" that appears to favour early successional species. On the other hand, where harvesting is not followed by site preparation, the forest floor may remain more or less intact relative to a fire-regenerated site. Intact forest floors appear to reduce the frequency of species with no seed bank, shallow roots and shade-adapted foliage, whereas high levels of disturbance favour wind-dispersed pioneers and spore-banking bryophytes (reviewed inVenier et al. 2014). Forest harvesting in temperate and boreal stands sometimes favours vascular species over bryophytes and ferns (Hart and Chen 2006), as well as the persistence of early successional species (Aubin et al. 2014). Old growth forest conditions 
can be associated with ant-dispersed, spring-flowering herbs and saprophytes such as Monotropa sp. (Aubin et al. 2014; Aubin et al. 2008).

Even partially harvested stands subject to different site preparation treatments can develop distinct understory assemblages. For example, red pine shelterwood-cut stands subject to prescribed burning support more resprouting and rhizomatous species, whereas species that regenerate from buried seed, such as Rubus strigosus, indicate the combined effects of mechanical site preparation and herbicide (D'Amato et al. 2011).

Observations such these have spurred speculation that forest management will reduce understory diversity relative to naturally regenerated stands (Aubin et al. 2008), and that differing management intensities will alter community diversity (Biswas et al., 2010). Beyond the aesthetic and ethical dimensions of potential species loss, ecologists are concerned that reduced diversity will compromise important ecosystem functions (e.g. carbon cycling, hydrology, nutrient retention) (Mayfield et al. 2010; Naeem and Wright 2003). These concerns have led researchers to move beyond taxonomic diversity to explore the role of functional diversity in ecosystems (Cadotte et al 2011). Functional traits have been defined as specific characters or phenotypic traits that are "associated with a biogeochemical process or ecosystem property" (Naeem and Wright 2003). However, "soft" traits, such as leaf area and seed mass have been used as surrogates for more difficult to measure "hard traits" (e.g. resource use, C: N ratio) that affect ecosystem function directly (Díaz et al. 2004). Soft traits, broadly interpreted, have been used to gain insights into community composition (Lavorel and Garnier 2002), ecosystem processes (Diaz et al. 2004), and increasingly, community responses to anthropogenic disturbances (Aubin et al. 2014; Aubin et al. 2007; Aubin et al. 2008; D'Astous et al. 2013). 
Whether or not taxonomic diversity (TD) contributes to functional diversity (FD) and ecosystem function partly depends on the degree to which species are functionally redundant for similar traits (Mayfield et al. 2010; Naeem and Wright 2003). The distribution of traits among relatively common or rare species affects the shape of the TD:FD relationship (see Fig. 2 in Naeem and Wright 2003). Environmental filters (e.g. shade and litter layers) imposed by the dominant tree species, environmental heterogeneity, and site productivity also regulate understory cover, composition, and diversity (Aubin et al. 2014; Reich 2012; Reich et al. 2012). Furthermore, we might expect forest stands that support higher overall vegetation cover to have higher TD - and by extension higher FD - based on random chance alone. This positive effect of cover (or abundance) on TD and FD is the basis of the sampling effect hypothesis (SEH), which posits that trait values accumulate with successive additive random draws from a regional species pool(Mayfield et al. 2010).

Bearing all of the above in mind, one of the forestry interventions with the greatest potential for changing TD and FD is stand conversion from one dominant tree species to another. Dominant tree species replacement may involve converting naturally generated polycultures to monoculture plantations (Ramovs and Roberts 2005; Veinotte et al. 2003), or less commonly, the transition of plantations back to native forest (Kerr et al. 2010; Parker et al. 2008). In this paper we investigate the consequences for understory TD and FD of converting managed and naturally regenerated jack pine (Pinus banksiana Lamb.) stands to plantations of red pine (Pinus resinosa Ait.). Based on prior observations across our 94 year chronosequence (Allard and Park 2013; Park 2015), we anticipated that the extensive litter layer and homogenous crown conditions imposed by red pine would lead to a general reduction in vegetation cover, and therefore, reduced TD of understory plants. We asked the following questions: 1) how do total TD and FD 
change across the chronosequence of red pine and jack pine stands; 2) how do stand environment and vegetation cover affect relationships between TD and FD among stands; 3) are there differences in the understory taxa present in red pine and jack pine stands across the chronosequence, and if so, do those differences have a qualitative effect on the functional traits represented; and 4) do environmental filters present in jack pine and red pine stands change during succession or among overstory species?

\section{Methods}

\subsection{Study area and site selection.}

Sandilands Provincial Forest (SPF, average coordinates $49^{\circ} 00^{\prime}-49^{\circ} 45^{\prime} \mathrm{N}$ and $96^{\circ} 15^{\prime}-96^{\circ} 49^{\prime}$ W) occupies $2772 \mathrm{~km}^{2}$ of gently rolling topography in southeast Manitoba. Climate is subhumid continental, with mean January and July temperatures of $-17^{\circ} \mathrm{C}$ and $19^{\circ} \mathrm{C}$, respectively, and annual precipitation of $540 \mathrm{~mm} \mathrm{yr}^{-1}, 80$ percent of which falls as rain (based on $1971-2000$ normals, Environment Canada 2015).

Much of SPF is dominated by fire-origin and planted jack pine stands and red pine plantations, which occupy well-drained dystric brunisols on beach ridges deposited by proglacial Lake Agassiz (see www.gov.mb.ca and Smith and Ehrlich 1964). Soil texture was quite homogeneous among sites; all sites were either pure sand or sandy-loam. Average soil pH was between 4.20 and 5.91 in the top $15 \mathrm{~cm}$, and organic matter ranged from $17-40 \mathrm{t} \mathrm{ha}^{-1}$ (Brian Desautels, unpublished data). Sandilands Provincial Forest has been managed for sustained yield forestry by the Government of Manitoba for almost a century. Although a few fire-origin red pine stands exist in peripheral areas of SPF, most red pine are in plantations established following the clearcut harvesting of jack pine. Likewise, most jack pine stands have also been planted following clearcut or salvage harvesting after stand-replacing fires. 
Twenty jack pine and 17 red pine sites were chosen for sampling. The main criterion for stand selection was that the dominant pine species represented at least 80 percent of the canopy cover. Occasional individuals and small groups of trembling aspen (Populus tremuloides Michx.), paper birch (Betula papyrifera Marsh.), white spruce (Picea glauca (Moench) Voss.), and balsam fir (Abies balsamea L. (Mill.)) were also present in some stands. Sites ranged from 10 to 105 years of age. All but one of the red pine stands were plantations, while 16 of 20 jack pine stands were planted. Naturally regenerated stands were all older than 40 years. Site preparation on planted sites was done by disc trenching or drag scarification with barrels and chains (Manitoba Conservation, Pineland Region, Steinbach Office Management records, 2012). This type of site preparation often left a legacy of ridge and berm microtopography that remained visible in even mature stands.

\subsection{Sampling trees, environment, and understory vegetation.}

Understory diversity was sampled as part of a larger project to compare ecosystem carbon storage across the jack pine and red pine chronosequence (full details in Park 2015). At each

site, living and dead trees $\geq 1.5 \mathrm{~m}$ tall were completely enumerated in a $12.62 \mathrm{~m}$ radius $\left(500 \mathrm{~m}^{2}\right)$ permanent sampling plot (PSP) that conformed to the design criteria of Manitoba Conservation's Forest Inventory Program (Manitoba Conservation, unpublished document; see Figure 1).

In addition to mensuration, we gathered data on several environmental variables in and around each PSP. Soil samples were taken in each stand from four $15 \mathrm{~cm}$ deep soil cores placed at random within the PSP, and a single $1 \mathrm{~m}^{3}$ soil pit located just outside the PSP border using the National Forest Inventory protocol (see Figure 1; NFI Task Force 2008). Soil texture, organic matter, and $\mathrm{pH}$ were estimated using pipette, loss on ignition, and the $1: 2 \mathrm{CaCl}_{2}$ method, 
respectively (Agriculture Canada 1984). Four fisheye photographs of the canopy were taken from the half-way mark of each polar axis of each PSP using a Nikon Coolpix 4500 equipped with a Nikon FC-E8 fisheye attachment. Canopy percent cover was averaged from the four photographs, which were processed using Gap Light Analyzer (GLA, Frazer et al. 1999).

Understory vegetation was sampled in $1 \mathrm{~m}^{2}$ quadrats placed along two $20 \mathrm{~m}$ transects, which were placed perpendicular to each other, tangential to the outer edge of the PSP (Figure 1). Twenty quadrats per stand were sampled by placing quadrats every second meter along the length of each transect. A coin toss determined whether quadrats would be placed at odd $(1,3,5 .$.$) or even (2,4,6 \ldots)$ meter spacing. Percent cover of all understory vascular plants, horsetails, ferns, mosses, lichens, tree seedlings and saplings $\leq 3 \mathrm{~m}$ tall, and shrub species of any height was estimated by eye. Observers distinguished the following cover categories: $0-1 \%,>1$ $2 \%,>2-5 \%$, and then in five percent intervals: $10 \%, 15 \% \ldots . .100 \%$. Litter cover and the cover of woody debris were estimated in the same way. Each site was surveyed twice, once in the spring and early summer (mid-May - July 14), and again in late summer (July 15 - late August) to maximize our chances of sampling vascular plants during their flowering period. Three stands experienced intermittent crown fires between field seasons and were therefore sampled only once.

The majority of vascular plants, including grasses were identified to species. Those that could not be firmly allocated to a species were identified to genus or, in a few cases only, to morphospecies. The most common mosses (e.g. Pleurozium schreberi, Hylocomium splendens) were always identified to species level, while some genera with multiple similar species (e.g. Dicranum, Polytrichum, Thuidium) were identified to genus. Lichens were allocated to genus only, with the exception of the easily identified species Cladina rangifer and Cladina mitis. The 
main botanical authorities consulted for current nomenclature were The Plants of Canada Database (Canadian Forest Service 2013), Vascan (Canadensys Undated), and Budd et al. (1979). Additional specialist sources were used to confirm the identification of shrubs, ferns and fern allies, mosses, and lichens.

\subsubsection{Plant functional traits}

We used the Traits of Plants in Canada (TOPIC) data base (Aubin et al. 2007) as our primary source for functional trait values. The TOPIC database is compiled from multiple sources, and embraces four major categories of "soft" traits (sensu Diaz et al 2005): morphology and adult life forms, regeneration and dispersion syndrome, resource use, and miscellaneous others. In this analysis we used only those life form, dispersal, morphological traits that were well represented in the TOPIC database (Table 1). Additional traits for moss flora were compiled from the literature, since mosses are not represented in TOPIC.

\subsection{Data analysis}

\subsubsection{Preparation of TD and FD indices.}

Percent cover in spring and summer quadrat surveys was averaged for species that were recorded during both seasons. For species that were observed during one season only, we used the singular percent cover values recorded in that season. These values were then used to calculate the mean cover of each species across the 20 quadrats in each stand. Taxonomic richness was expressed both as total species richness per stand, mean species richness per quadrat, and as the number of species per quadrat divided by total percent cover per quadrat (species per percent). Species per percent was calculated to explore potential sampling effects as described above. The inverse of Simpson's diversity index (hereafter "Simpson's D”) was used as a general index of 
TD. Species evenness was calculated using Simpson's Evenness (hereafter “Evenness”), which is independent of species richness (Magurran 2004) (Table 2).

Measuring FD is complicated by the fact that, unlike unitary taxa, traits may be measured on different scales (e.g. continuous, ordinal, nominal) and species may assume more than one trait state. A wide variety of indices has been proposed and their correct interpretation is subject to debate (Mouchet et al. 2010; Schleuter et al. 2010). In this paper, we adopt the approach of Villéger et al (2008) and Mouchet et al (2010), who suggest using discrete indices to measure three fundamental aspects of FD: functional richness, functional evenness, and functional divergence (Table 2). Functional richness (FRic) describes the degree to which multivariate functional trait space is occupied by a given species assemblage. Functional evenness (FEve) refers to the regularity of species abundances in functional trait space. Functional divergence (FDiv) defines the relative dispersal of species around the centre of gravity of the functional trait space. Specifically, FDiv relates to how spread-out or how clumped species are in niche space, weighted by their relative abundance (Villéger et al. 2008). FEve and FDiv are constrained to a range of $0-1$, while FRic can take any value. All three indices have been demonstrated to be mutually independent (Villéger et al 2008).

\subsubsection{Statistical analysis}

Data were analyzed using univariate and multivariate techniques. Exploratory scatter plots and previous analyses (Allard and Park 2013, Park, 2015) suggested that red pine and jack pine data had different variance structures. We therefore used generalized least squares regressions (GLS; Zuur et al. 2009) to investigate the effects of dominant overstory species, stand age, canopy closure, litter cover, litter depth, and soil organic matter on stand-level TD and FD indices (Questions 1). Exploratory analyses relating FD to TD, and average total percent cover to both 
FD and TD, were performed to answer Question 2. Multivariate techniques were used to explore the distribution of taxa, individual traits and trait associations among stands, using the same environmental variables that were used in GLS (Questions 3 and 4).

Generalized least squares are linear models in which explanatory variables can be weighted in a variety of ways to compensate for heterogeneous and non-normal residuals (Zuur et al. 2009). Following Zurr et al (2009), GLS models were calculated, using several different weightings, for each TD and FD index. Models using different weightings can be compared using Akaike and Baysian information criteria (AIC and BIC), and using standard quantilequantile plots to inspect standardized residuals. The basic GLS model we deployed was:

$$
\mathrm{I}_{\mathrm{i}}=\mathrm{S}_{\mathrm{j}}+\mathrm{A}_{\mathrm{i}}+\mathrm{LC}_{\mathrm{i}}+\mathrm{LD}_{\mathrm{i}}+\mathrm{C}_{\mathrm{i}}+\mathrm{O}_{\mathrm{i}}+\varepsilon \quad \text { Equation } 1
$$

where $I_{i}$ is the value of a given index in stand $i, S_{j}$ is overstory species (jack pine or red pine), $A_{i}$ is stand age, $\mathrm{LC}_{\mathrm{i}}+\mathrm{LD}_{\mathrm{i}}$ are litter depth and litter cover, respectively, $\mathrm{C}_{\mathrm{i}}$ is crown closure, $\mathrm{O}_{\mathrm{i}}$ is organic matter content in the top $15 \mathrm{~cm}$ of soil, and $\varepsilon$ is error. Additional explorations of the relationships among TD and FD indices (Question 2) were done using multiple Pearson correlations on the split data of red pine and jack pine.

Multivariate distributions of taxa and traits among dominant overstory species, stand age, and other environmental variables were analyzed using RLQ and fourth corner analysis (Dray et al. 2014; Dray and Legendre 2008). These two analyses are complementary. The RLQ technique is an extension of co-inertia analysis that summarizes the joint multivariate structure of three matrices, R: sites by environmental variables, L: sites by species cover, and Q: species by traits (Dray et al. 2014). The goal of RLQ is to maximize the covariance between the trait and environmental matrices as mediated by the matrix of species abundances. Separate ordinations of environmental gradients (R), patterns among species (L), and distribution and organization of 
traits (Q) are first calculated. These ordinations are then linked through and made comparable using a fourth matrix $\Omega$ of environmental variables by traits, which is a measure of the intensity with which traits are linked to the environment.

Fourth corner analysis also uses matrix $\Omega$ to evaluate the statistical significance of each bivariate trait-environmental variable relationship. Correlations are calculated for each traitenvironment pair, and $\mathrm{P}$-values calculated using two randomization procedures. One procedure (Model 2) randomly permutes sites (rows of $\mathrm{R}$ or $\mathrm{L}$ ) to test the null hypothesis $\left(\mathrm{H}^{\circ}\right)$ that the distribution of species with fixed traits is not influenced by environmental variables. The second permutation (Model 4) tests the $\mathrm{H}^{\mathrm{o}}$ that the species composition (rows of Q or columns of L) of samples with fixed environmental characteristics is uninfluenced by traits. This $\mathrm{H}^{\mathrm{o}}$ assumes no relationship between $\mathrm{L}$ and $\mathrm{Q}$ (when the R-L link is preserved). In the combined approach of Dray et al. (2014), Model 4 is calculated only in the event that Model 2 rejects $\mathrm{H}^{\mathrm{o}}$, and the traitenvironment associations are considered significant only if the largest of the two $\mathrm{P}$ values is lower than the chosen alpha $(\alpha)$. This combined approach allows for the calculation of unbiased P-values.

All statistical analyses were done using R software (R Development Core Team 2014). Functional trait indices were generated in the package FD (Laliberté 2014), and those for biological diversity were calculated in Vegan (Jari Oksanen et al. 2013). The RLQ and Fourth Corner analyses were done using ade4 (Dray et al. 2014; Dray and Dufour 2007). The RLQ analysis used correspondence analysis for species ordination, and separate principal components analyses for environmental and trait variables. The fourth corner was done using 49,999 random permutations of sites and species and P-values were calculated using "model 6", Dray et al.'s (2014) combined approach. We did not correct P-values for false discovery rates, because we 
considered that correcting the 350 trait-environment tests included in the fourth corner analysis would have greatly inflated the probability of committing a Type II error. Missing trait values for particular species were replaced with the global means for the given trait using the missMDA library. Generalised least squares models were calculated using package nlme (Pinheiro et al. 2014).

\section{Results}

\subsection{General community patterns}

We recorded 151 vascular and non-vascular species for which complete or nearly complete sets of traits were available. Ninety-one species occurred in both jack pine and red pine stands; 43 were unique to jack pine, and 17 were found exclusively in red pine. Unique species were always rare, occurring in four or fewer stands in all cases (Table S1). Stands that burned before a second round of sampling could be done were 11 and 38 year old jack pine stands (one spring and one summer inventory), and a 28 year old red pine stand (spring inventory). The 11-year old jack pine stand had the lowest species richness among the 37 stands (20 species), and although the other two stands had lower than average richness (27 and 28 species), these data fell well within the range of species richness found in stands of similar age.

Traits were also unevenly distributed. Hemicryptophytes, geophytes and microphanerophytes were the most common growth forms, constituting 106 of 151 species. Reproduction by rhizomes was the most common mode of vegetative reproduction (105 species), followed by root collar sprouting (19 species), fragmentation (14 species), layering (11 species) and rhizoids (10 species, restricted to mosses). Seed plants were predominantly wind-dispersed (83 species), spread by endozoochory (35 species, mostly by birds), or by explosive dispersal (13 species). 


\subsection{TD and FD indices}

Exploratory scatterplots indicated potential species-age interactions for some TD and FD variables. We therefore fitted GLS models with and without species-age interactions. Exploratory graphics (Figures 2 and 3), together with previous analysis of stand structure and carbon storage (Park 2015, Allard and Park 2013), suggested that the oldest, fire origin red pine stand was a strong outlier within its species stand grouping. We therefore excluded this stand from GLS analysis.

In all analyses, the variance structure that yielded the best models assumed different standard deviations for jack pine and red pine stand groupings. Tree species and age significantly $(\mathrm{P} \leq 0.05)$ affected five of six TD indices before species:age interactions were taken into account (Table 3). Taxonomic diversity generally declined with stand age. Red pine had lower values of each index than jack pine, and tended to show a fairly clear decline in TD with age, whereas jack pine stands were more variable and showed no clear TD-age relationship (Figure 2, a-f). Species per percent cover was the exception to this general pattern, appearing to increase with stand age in red pine but not in jack pine. Evenness differed from other TD indices by being weakly and positively associated with litter depth, in addition to being negatively affected by age.

Inclusion of species-age interactions reduced the values and statistical significance of species and age coefficients in five of six TD models. Variance inflation factors (VIF) indicated that the inclusion of species-age interactions had introduced substantial collinearity. The VIFs generally increased from $\leq 2$ in models without interactions to $>7$ for species and $>2.5$ for age in models that included the interaction term. In these five TD models, the species-age interactions were statistically significant, and confirmed the tendency of index values in red pine and jack 
pine to diverge with increasing stand age. When considered together with the scatterplots of Figure 2, the interaction terms indicate similar TD values in young stands, with values of species richness, richness per quadrat, total cover, and Simpson's D declining with age in red pine, but being little affected in jack pine.

Neither the convex hull volume enclosing trait space (FRic) nor the evenness with which species occupied this space (FEve) differed between species or with age. Furthermore, FRic and FEve were not significantly affected by any environmental variable. These indices showed a wide scatter among stands, with co-mingling of red and jack pine stands at all ages (Figure 3a, b). Functional divergence (FDiv, the Euclidean distances of traits from their mean value) was significantly larger with increasing litter cover, implying that high litter cover favoured extreme trait values among the most abundant species (Figure 4a). FDiv also had marginally non-significant negative relationships with species and age $(\mathrm{P}=0.07)$. The inclusion of a significant species-age interaction increased the positive coefficient and P-value of litter cover in the FDiv model (Figure 3c).

\subsubsection{Correlations.}

Average total cover per quadrat correlated strongly with total species richness, richness per quadrat, and Simpson's D in red pine but not in jack pine (Table 4). Similarly, Simpson's D was strongly correlated with all measures of species richness in red pine, and with richness and richness per quadrat in jack pine. Richness per percent was significantly and negatively correlated with both total richness and richness per quadrat in red pine, but not in jack pine. Richness per percent also exhibited a strong negative exponential relationship with total vegetation cover of the type $y=a-b * \exp ^{\left(c^{*} x\right)}$, where $x$ is total vegetation cover and $a, b$, and $c$ are coefficients to be calculated (Figure 4b). Functional trait indices were uncorrelated with all 
indices of species richness, but FDiv was positively correlated with Simpson's D in red pine and positively correlated with Evenness in jack pine (Table 4).

\subsection{RLQ and Fourth Corner analyses}

\subsubsection{RLQ.}

The trait-environment relationship in the RLQ analysis was highly significant overall $(\mathrm{P} \leq 0.01)$, and the first two axes of the analysis captured $75.5 \%$ and $16.1 \%$ of the trait-environment crosscovariance respectively (Figure 5). Patterns among traits and environmental variables in separate PCAs were well conserved in the RLQ analysis ( $>85 \%$ of the original variance conserved, Table 5). However, correlations between traits and environment mediated by species were relatively low ( 0.46 and 0.36 for axes 1 and 2 , respectively).

The primary biplot axis for environmental scores in the RLQ illustrates a gradient between increasing stand age and crown closure (positive scores) and litter qualities (negative scores) (Figure 5, "R"). Axis two of this biplot clearly shows the separation of jack pine and red pine stands on the basis of greater litter cover and canopy closure in red pine stands and higher tree density in jack pine (See also Table S2). The primary axis of the traits biplot (Figure 5, "Q") separated pleurocarpus mosses, particularly Pleurozium schreberi, shade-tolerant herbs, and angiosperms dispersed by endozoochory from traits associated with deciduous perennials. The secondary traits axis separated wind-dispersed plants, geophytes, tall species, and acrocarpus mosses (associated with high litter cover) from a larger suite of traits loading relatively weakly at the positive end of the axis, which were not strongly correlated to any particular environmental variable (Table S3).

As suggested by the traits biplot, non-vascular plants dominated the positive side of the first species axis. Species with a wide variety of life forms and reproductive strategies loaded 
onto the negative end of this axis, with the most influential groups being shrubs (e.g. Alnus viridis, Amelanchier sp.), and a suite of species broadly associated with more open canopies (e.g Lathyrus ochroleucus, Aralia hispidula), or even disturbed environments (Plantago major). Some of these species disperse their seeds explosively (e.g. Lathyrus ochroleucus, Vicia Americana). The negative side of the second species axis was dominated by seedlings of conifers, together with shrubs and woodland herbs (e.g. Anemone spp.) that are mid-tolerant to tolerant of shade. Only $P$. major had an eigenvalue $>2.0$ on the positive side of this axis.

\subsubsection{Fourth Corner.}

Results of the fourth corner analysis largely supported the patterns revealed by RLQ. Twenty four of 350 environment-trait tests returned statistically significant correlations, although we note that these results should be interpreted with caution, since a false discovery correction was not applied. Statistically significant trait-environment correlations were relatively low $(\mathrm{r} \leq 0.3$; Table S4). The most influential environmental variables were stand age, canopy closure, and litter depth (Figure 6). Stand age and canopy closure were positively correlated with pleurocarpus mosses and vegetative reproduction through fragmentation, and negatively correlated with deciduousness and a perennial life history. Litter depth was also positively associated with deciduousness and perennialism, while both litter cover and depth were associated negatively with pleurocarpus mosses and endozoochory. Jack pine and red pine were only associated with two traits; acrocarpus mosses and wind-dispersed species were negatively associated with jack pine but positively associated with red pine. These results should be interpreted with caution, since 


\section{Discussion}

\subsection{TD, FD, and the stand environment.}

Taxonomic diversity (TD) was more responsive than functional diversity (FD) to overstory tree species and stand age (Question 1). Indices of TD were more responsive to stand age in red pine than in jack pine stands, (Question 1), and red pine stands appeared to impose more environmental filters on TD than jack pine (Question 2). With the exception of litter cover and depth, TD and FD indices were unaffected by physical environmental variables (Question 2, Table 3; Figure 3a,b).

The increased species evenness observed with litter depth might have resulted from an alleviation of interspecific competition in deep litter layers. However, species evenness was poorly correlated with species richness and vegetation cover. Deep litter layers did not, therefore, directly influence evenness by reducing total cover, but may have acted as a selective filter by reducing the cover of species like Pleurozium schreberi, which spreads clonally to form continuous monocultures (see 4.2 below). High litter cover was also associated with high values of FDiv (Figure 4a), which implied that extensive litter inhibited species with average trait values, but favoured the abundance of species occupying the periphery of the multivariate trait space. Neither litter cover nor depth were associated with older stands (Figure 5), and although canopy closure was higher in old red pine, it did not strongly affect species TD or FD (Question 4).

Unlike TD, two out of three FD indices- FRic (size of the trait hypervolume) and FEve (dispersal of traits within the hypervolume) - varied independently of species richness (Table 4, Question 3). Our species pool may therefore have had high functional redundancy, perhaps because jack pine and red pine imposed similar environmental filters that favoured a limited 
range of traits, regardless of species richness, diversity, or vegetation cover. The sampling effect hypothesis (SEH), whereby functional diversity would increase or decrease with species richness, appears to have been falsified for red pine and jack pine understory communities (Mayfield et al. 2010).

The strong negative exponential relationship between richness per percent and average cover per quadrat is consistent with species richness "saturating" at high cover per quadrat (Figure $3 b$ ). In some mature red pine stands, average percent cover fell as low as 13\%, implying that mature red pine stands may have somewhat stressful understory environments, but little interspecific competitive pressure (low vegetation cover). Under such conditions of low total cover, each additional unit of vegetation cover seemed to increase the likelihood that available space would be occupied by a new species. By contrast, in stands with high total cover, any additional units of cover appeared more likely to be occupied by additional cover of species already present.

\subsection{RLQ and fourth corner.}

Although ordination (Figure 5) showed a tendency for some species to occur predominantly in either red pine or jack pine, species that were unique to one stand type or the other were rare in abundance (Table S1, Question 3). This finding suggests that species accumulated more or less randomly as vegetation cover increased, with dispersal limitation probably imposing a further filter on establishment in the case of rare species. Competitive space filling (i.e. each species usurping more space) at high total percent cover may have contributed further to the saturation of species richness within quadrats.

The complementary RLQ and fourth corner analyses support and shed additional insight on the GLS and correlation results. Although RLQ illustrated clear environmental differences 
between jack pine and red pine (Figure 5), only wind-dispersed species and acrocarpus mosses were associated with stands of a specific overstory species. Six other traits were either negatively or positively associated with stand age, canopy closure and litter cover (Question 4, Figure 6). Shade tolerance and vegetation reproduction from fragments could be expected to be positively associated with older stands with high canopy cover. These traits may covary if they constitute part of a trait complex defining, for example, pleurocarpus mosses, which were also more common in older stands. Similarly, the positive associations between perennial and deciduous traits and litter depth could reflect positive feedbacks from deciduousness to litter depth.

Positive associations between endozoochory (mostly by birds) and older stands with high woody debris cover could indicate that these stands were particularly attractive to seeddispersing birds. Alternatively, other properties of the stand might have been conducive to the germination of bird-dispersed seeds. The lack of environmental correlations among the other 25 traits represented in the fourth corner analysis supports the general findings from GLS that stand environments were weak filters of FD (Question 4).

\subsection{Comparison with other studies.}

Researchers have adopted a variety of approaches analyzing FD, which complicates attempts to compare different studies. Different FD indices are recommended by different authors. In our approach, we followed Mouchet et al. (2010), because i) the three indices FRic, FEve, and FDiv measure complementary aspects of FD with different relationships to ecosystem properties, and ii) techniques based on cluster analysis of raw traits suffer from loss of information. Rao's Quadratic Entropy (Q) has been recommended (Schleuter et al. 2010) and deployed as a single measure of functional diversity (e.g. Aubin et al. 2013), but Q conflates functional richness and 
divergence, making the interpretation of this index somewhat complex (Mouchet et al 2010).

Some studies do not calculate functional indices, but combine raw traits into a communityweighted mean (CWM) matrix from the L and Q matrices, and subject this new matrix to PCA or

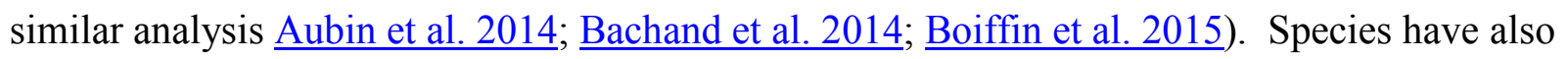
been categorized into emergent groups that represent coherent trait groupings using cluster analysis (Aubin et al. 2007; Aubin et al. 2008). In at least one study, the total number of traits in a plot or site were summed into trait richness in a manner analogous to species richness as the number of species (Biswas and Malik 2011). This approach falls foul of the fact that traits do not attach uniquely to unitary species. Rather, species are represented by multiple traits, which generates the requirement that FD be defined by a multidimensional trait space (Villéger et al, 2008).

Our results differed from those of many studies by having a relatively random distribution of traits among stand types, with few statistically significant trait-environment associations. Aubin et al. (2013) found that most plant traits had significant positive or negative correlations with stand age classes in a chronosequence of 64 post-harvest jack pine stands. Comparing FD in natural temperate hardwood stands with deciduous and coniferous monocultures, Aubin et al. (2008) found distinct emergent groups (trait groupings established by cluster analysis) to be associated with different successional stages. They also found that FD converged with age in deciduous plantations and natural forest, but that coniferous plantations followed a completely different successional trajectory. Taking a similar approach, Aubin et al. (2007) found broadly similar vegetation assemblies among disturbed and undisturbed sugar maple stands in southern Quebec, but that spring geophytes and some shade-tolerant forbs had decreased cover in disturbed habitats. Boiffin et al. (2015) used a series of partial redundancy 
analyses to partition environment-trait correlations among Quebec fire regions, topo-sequences within regions, and plots within topo-sequences. These authors found little trait-environment correlation at across large fire regions because biological legacies from pre-fire stands tended to persist after low severity fires. At more local (plot and topo-sequence) scales, however, these authors found that jack pine plots where duff (humus) layers had been lost to hot fires supported plant communities with the widest variety of regeneration and dispersal traits.

It is clear that the results of FD analyses depend both on the environmental context and the analytical technique used. Temperate broadleaves, post-fire boreal forests, plantations, and extensively managed forests support different understory species assemblages that in turn have characteristic mixtures of traits. But where overstory species are similar, or where disturbance leaves remnant patches of vegetation or seed banks from previous stands, communities may be broadly similar. This may have been the case in our coniferous chronosequence, in which both jack pine and red pine were established after clearcut harvesting. Clearcutting may leave more biological legacies than, for example, a severe fire. Indeed, TD may be greater in post-harvest boreal stands than in post-fire stands, but be similar in older stands regardless of disturbance regime (Reich et al. 2001).

Finally, no other study that we reviewed divided FD into FRic, FEve and FDiv. These metrics allowed us to examine three subtly distinct aspects of FD (Villéger et al 2008), and deduce that stand environment affected FDiv (distribution of species with relatively extreme trait values), but not FEve or FRic. Villéger et al (2008) and Mouchet et al (2010) believe that decomposing FD into three indices provides insights into ecosystem functioning and the environmental filters that affect FD. However, the absence of studies taking a similar approach makes direct comparisons with our study difficult. Because of the complexity of TD-FD 
relationships, we suggest that a standardized set of FD indices should be reported in each FD study, regardless of aims, to facilitate inter-study comparisons.

\section{Conclusions.}

Taxonomic diversity (TD) declined with age in red pine plantations but not in jack pine stands. However, environmental filters on TD were relatively weak, with only litter cover and depth affecting and affected only species evenness. There were few differences in the species represented in red pine and jack pine stands, and these were attributable to rare species whose occurrence was probably filtered by dispersal limitation. Likewise, although vegetation cover was consistently lower in red pine than in jack pine stands, species richness on a percent cover basis was greater in red pine, suggesting that richness might have saturated at high cover levels in jack pine due to interspecific competition. In contrast to TD, two of three FD indices were unaffected by the dominant overstory species, stand age, or environmental variables. Only FDiv was affected by stand environment, with litter cover favouring greater proportional cover by species whose traits occupied extremes of the trait value spectrum. We concluded that there was a high level of functional redundancy in our species pool for the suite of traits that we analyzed, and that this redundancy might have reflected similar sets of environmental filters imposed by the dominant overstory species.

\section{Literature Cited}

Agriculture Canada. 1984. Analytical Methods Manual (B. H. Sheldrick (ed). Land Resource Research Institute, Research Branch, Agriculture Canada. LRRI Contribution No. 84-30. Allard, J., and Park, A. 2013. Woody debris volumes and carbon accumulation differ across a chronosequence of boreal red pine and jack pine stands. Canadian Journal of Forest Research 43: $768-775$. 
Aubin, I., Deshaies, O., Cardou, F., and Sirois, L. 2014. Management legacy in the understory of North American mixed boreal regenerating stands. Forest Ecology and Management 320: 129-137.

Aubin, I., Gachet, S., Messier, C., and Bouchard, A. 2007. How resilient are northern hardwood forests to human disturbance? An evaluation using a plant functional group approach. Ecoscience 14: 259-271..

Aubin, I., Messier, C., and Bouchard, A. 2008. Can plantations develop understory biological and physical attributes of naturally regenerated forests? Biological Conservation 141: 24612476.

Aubin, I., Venier, L., Pearce, J., and Moretti, M. 2013. Can a trait-based multi-taxa approach improve our assessment of forest management impact on biodiversity? Biodiversity and Conservation 22: 2957-2975.

Bachand, M., Pellerin, S., Moretti, M., Aubin, I., Tremblay, J.P., Cote, S.D., and Poulin, M. 2014. Functional responses and resilience of boreal forest ecosystem after reduction of deer density. PLoS ONE 9 (2). doi: e9043710.1371/journal.pone.0090437.

Biswas, s.R., and Malik, A.U. 2011. Species diversity and functional diversity relationship varies with disturbance intensity. Ecosphere 2 (4): Article 52.

Boiffin, J., Aubin, I., and Munson, A.D. 2015. Ecological controls on post-fire vegetation assembly at multiple spatial scales in eastern North American boreal forests. Journal of Vegetation Science 26: 360-372.

Boucher, Y., Arseneault, D., and Sirois, L. 2006. Logging-induced change (1930-2002) of a preindustrial landscape at the northern range limit of northern hardwoods, eastern Canada. Canadian Journal of Forest Research 36: 505-517. 
Brassard, B.W., and Chen, H.Y.H. 2008. Effects of forest type and disturbance on diversity of coarse woody debris in boreal forest. Ecosystems 11: 1078-1090.

Budd, A.C., Looman, J., and Best, K.F. 1979. Budd's Flora of the Canadian Prairie Provinces. . Agriculture Canada, Ottawa.

Canadensys. Undated. Vascan. Available from http://data.canadensys.net/vascan/search [Accessed April 5th, 2015].

Canadian Forest Service. 2013. Plants of Canada database. Available from http://www.plantsofcanada.info.gc.ca/ [Accessed April 5th, 2015].

D'Astous, A., Poulin, M., Aubin, I., and Rochefort, L. 2013. Using functional diversity as an indicator of restoration success of a cut-over bog. Ecological Engineering 61: 519-526.

D’Amato, A.W., Segari, J., and Gilmore, D. 2011. Influence of site preparation on natural regeneration and understory plant communities within red pine shelterwood systems. Northern Journal of Applied Forestry 29: 60-66.

Díaz, S., Hodgson, J.G., Thompson, K., Cabido, M., Cornelissen, J.H.C., Jalili, A., MontserratMartí, G., Grime, J.P., Zarrinkamar, F., Asri, Y., Band, S.R., Basconcelo, S., Castro-Díez, P., Funes, G., Hamzehee, B., Khoshnevi, M., Pérez-Harguindeguy, N., Pérez-Rontomé, M.C., Shirvany, A., Vendramini, F., Yazdani, S., Abbas-Azimi, R., Bogaard, A., Boustani, S., Charles, M., Dehghan, M., Torres-Espuny, L.d., Falczuk, V., Guerrero-Campo, J., Hynd, A., Jones, G., Kowsary, E., Kazemi-Saeed, F., Maestro-Martínez, M., Romo-Díez, A., Shaw, S., Siavash, B., Villar-Salvador, P., and Zak, M.R. 2004. The plant traits that drive ecosystems: Evidence from three continents. Journal of Vegetation Science 15: 295-304. 
Dray, S., Choler, P., Dolédec, S., Peres-Neto, P.R., Thuiller, W., Pavoine, S., and Braak, C.J.F.t. 2014. Combining the fourth-corner and the RLQ methods for assessing trait responses to environmental variation. Ecology 95: 14-21.

Dray, S., and Dufour, A.B. 2007. The ade4 package: implementing the duality diagram for ecologists. Journal of Statistical Software 22: 1-20.

Dray, S., and Legendre, P. 2008. Testing the species traits-environment relationships: The fourth corner problem revisited. Ecology 89: 3400-3412.

Environment Canada, 2015. Canadian Climate Normals 1971 - 2000. Available from http://climate.weather.gc.ca/climate_normals/results_e.html?stnID=3675\&lang=e\&amp;Stati onName $=$ Steinbach\&amp;Search Type $=$ Contains $\&$ amp $;$ stnNameSubmit $=$ go $\& d$ Code $=1 \&$ disp Back=1 [accessed March 5th, 2015].

Fonder, W. 2007. Stand conversion for sustainable forestry. In Quo Vadis, Forestry?, Proceedings. Edited by Z. Sierota. pp. 257-267.

Frazer, G.W., Canham, C.D., and Lertzman, K.P. 1999. Gap Light Analyzer (GLA), Version 2.0: Imaging software to extract canopy structure and gap light transmission from true-colour fisheye photographs, users manual and program documentation. Simon Fraser University, Burnaby, British Columbia, and the Institute of Ecosystem Studies, Millbrook, New York.

Hart, S.A., and Chen, H.Y.H. 2006. Understory vegetation dynamics of North American boreal forests. Critical Reviews in Plant Sciences 25: 381-397.

Hearndon, K.W., Millson, S.V., and Wilson, W.C. 1992. A report on the status of forest regeneration by the Ontario Indep-endant Forest Audit Committee. Ontario Ministry of Natural Resources. 
Jari Oksanen, F. Guillaume Blanchet, Roeland Kindt, Pierre Legendre, Peter R. Minchin, R. B. O'Hara, Gavin L. Simpson, Peter Solymos, M. Henry, H. Stevens, and Wagner, H. 2013. vegan: Community Ecology Package.

Kerr, G., Morgan, G., Blyth, J., and Stokes, V. 2010. Transformation from even-aged plantations to an irregular forest: the world's longest running trial area at Glentress, Scotland. Forestry 83: 329-344.

Laliberté, E., Legendre, P., and B. Shipley. 2014. FD: Measuring functional diversity from multiple traits, and other tools for functional ecology. R package version 1.0-12.

Lavorel, S., and Garnier, E. 2002. Predicting changes in community composition and ecosystem functioning from plant traits: revisiting the Holy Grail. Functional Ecology 16: 545-556.

Mayfield, M.M., Bonser, S.P., Morgan, J.W., Aubin, I., McNamara, S., and Vesk, P.A. 2010. What does species richness tell us about functional trait diversity? Predictions and evidence for responses of species and functional trait diversity to land-use change. Global Ecology and Biogeography 19: 423-431.

Magurran, A.E. 2004. Measuring biological diversity. Blackwell Science Ltd., Oxford UK. pp. 256.

Mouchet, M.A., Villeger, S., Mason, N.W.H., and Mouillot, D. 2010. Functional diversity measures: an overview of their redundancy and their ability to discriminate community assembly rules. Functional Ecology 24: 867-876.

Naeem, S., and Wright, J.P. 2003. Disentangling biodiversity effects on ecosystem functioning: deriving solutions to a seemingly insurmountable problem. Ecology Letters 6: 567-579. NFI Task Force. 2008. Canada's National Forest Inventory Ground Sampling Guidelines. Canadian Forest Service / Canadian Council of Forest Ministers. Version 5.0. 
Niemelä, J. 1997. Invertebrates and boreal forest management. Conservation Biology 11: 601610.

Park, A. 2015. Carbon storage and stand conversion in a pine-dominated boreal forest landscape. Forest Ecology and Management 340: 70-81.

Parker, W.C., Elliott, K.A., Dey, D.C., and Boysen, E. 2008. Restoring southern Ontario forests by managing succession in conifer plantations. Forestry Chronicle 84: 83-94.

Pettersson, R.B. 1997. Lichens, invertebrates and birds in spruce canopies: impacts of forestry. Acta Universitatis Agriculturae Sueciae Silvestria 16: 1-36.

Pinheiro J, Bates D, DebRoy S, Sarkar D, and R Core Team. 2014. nlme: Linear and nonlinear mixed effects models.

R Development Core Team. 2014. R: A Language and environment for statistical computing. R Foundation for Statistical Computing, Vienna, Austria.

Ramovs, B.V., and Roberts, M.R. 2005. Response of plant functional groups within plantations and naturally regenerated forests in southern New Brunswick, Canada. Canadian Journal of Forest Research 35: 1261-1276.

Reich, P.B. 2012. Key canopy traits drive forest productivity. Proceedings of the Royal Society B-Biological Sciences 279: 2128-2134.

Reich, P.B., Bakken, P., Carlson, D., Frelich, L.E., Friedman, S.K., and Grigal, D.F. 2001. Influence of logging, fire and forest type on biodiversity and productivity in southern boreal forests. Ecology 82: 2731-2748.

Reich, P.B., Frelich, L.E., Voldseth, R.A., Bakken, P., and Adair, E.C. 2012. Understorey diversity in southern boreal forests is regulated by productivity and its indirect impacts on resource availability and heterogeneity. Journal of Ecology 100: 539-545. 
Schleuter, D., Daufresne, M., Massol, F., and Argillier, C. 2010. A user's guide to functional diversity indices. Ecological Monographs 80: 469-484.

Smith R E, and Ehrlich W A. 1964. Report of the soil survey of the south-eastern map sheet area. .Manitoba Department of Agriculture and Conservation. . Manitoba Soil Survey. Soils Report 14.

Sturtevant, B.R., Bissonette, J.A., Long, J.N., and Roberts, D.W. 1997. Coarse woody debris as a function of age, stand structure, and disturbance in boreal Newfoundland. Ecological Applications 7: 702-712.

Veinotte, C., Freedman, B., Maass, W., and Kirstein, F. 2003. Comparison of the ground vegetation in Spruce Plantations and Natural Forest in the Greater Fundy Ecosystem, New Brunswick Canadian Field Naturalist 117: 531-540.

Venier, L.A., Thompson, I.D., Fleming, R., Malcolm, J., Aubin, I., Trofymow, J.A., Langor, D., Sturrock, R., Patry, C., Outerbridge, R.O., Holmes, S.B., Haeussler, S., Grandpré, L.D., Chen, H.Y.H., Bayne, E., Arsenault, A., and Brandt, J.P. 2014. Effects of natural resource development on the terrestrial biodiversity of Canadian boreal forests. Environmental Reviews 22: 457-490.

Villéger, S., Mason, N.W.H., and Mouillot, D. 2008. New multidimensional functional diversity indices for a multifaceted framework in functional ecology. Ecology 89: 2290-2301.

Zuur, A.F., Ieno, E.N., ', N.J.W., Saveliev, A.A., and Smith, G.M. 2009. Mixed effects models and extensions in ecology with R. Springer Science + Business Media, New York. pp. 574. 
Table 1. Biological traits of vascular and non-vascular plants used in this study. Traits for a majority of vascular plants, ferns and horsetails were derived from the TOPIC data base, whereas moss traits were derived from a variety of sources in the literature.

\begin{tabular}{|c|c|c|}
\hline Trait & Functional Diversity Indices & RLQ and $4^{\text {th }}$ Corner \\
\hline $\begin{array}{l}\text { Raunkier life } \\
\text { form } \dagger\end{array}$ & $\begin{array}{l}\text { Ordinal: } 1 \text { - Geophyte; } 2 \text { - Hemicryptophyte; } \\
\text { 3-Pleurocarpus moss; } 4 \text { - Acrocarpus moss; } \\
\text { 5-Chamaephyte; } 6 \text { - Microphanerophyte; } \\
7 \text { - Phanerophyte; } 8 \text { - Megaphanerophyte }\end{array}$ & $\begin{array}{l}\text { Dummy: codes as in previous } \\
\text { column }\end{array}$ \\
\hline Life cycle & Ordinal: 1 - Annual; 2 - Biannual; 3 - Perennial & $\begin{array}{l}\text { Dummy: codes as in previous } \\
\text { column }\end{array}$ \\
\hline Deciduousness & Dummy: Evergreen or Deciduous & Dummy: Evergreen or Deciduous \\
\hline $\begin{array}{l}\text { Flowering } \\
\text { Season }\end{array}$ & $\begin{array}{l}\text { Ordinal: } 1 \text { - spring; } 2 \text { - summer; } \\
\quad 3 \text { - late summer / fall }\end{array}$ & $\begin{array}{c}\text { Dummy: Categories as in } \\
\text { previous column. }\end{array}$ \\
\hline Seed Length & Continuous: $\mathrm{mm}$ & Continuous: $\mathrm{mm}$ \\
\hline $\begin{array}{l}\text { Maximum } \\
\text { height }\end{array}$ & Continuous: $\mathrm{cm}$ & Continuous: $\mathrm{cm}$ \\
\hline $\begin{array}{l}\text { Vegetative } \\
\text { Reproduction }:\end{array}$ & $\begin{array}{l}\text { Fuzzy variable: Colonial sprout; Creeping stem } \\
\text { Fragmentation; Layering; Rhizomes Rhizoids } \\
\text { (for moss only); Stem (epicormic) sprout; } \\
\text { Stump sprout; Fibrous roots }\end{array}$ & $\begin{array}{l}\text { Fuzzy variable: As in previous } \\
\text { column. }\end{array}$ \\
\hline Shade tolerance & $\begin{array}{l}\text { Ordinal: } 1 \text { - Intolerant; } 2 \text { - Mid-tolerant; } \\
\quad 3 \text { - Tolerant }\end{array}$ & Ordinal: As in previous column \\
\hline Seed dispersal $\uparrow$ & $\begin{array}{l}\text { Fuzzy variable: Insect; Bird; Water; Explosive; } \\
\text { Endozoochorus (ingested); Unassisted; } \\
\text { Human; Wind; Exozoochorus (carried) }\end{array}$ & $\begin{array}{l}\text { Fuzzy variable: As in previous } \\
\text { column. }\end{array}$ \\
\hline
\end{tabular}

$\dagger$ Raunkier life forms are based on the form and height of perennating bud: Geophytes underground bulbs or tubers; Hemicryptophyte - soil level. Pleurocarpus moss - No perennating bud - creeping moss; 4 - Acrocarpus moss - Upright moss; Chamaephyte - bud $0.1-25 \mathrm{~cm}$ above ground; Microphanerophyte $-25 \mathrm{~cm}-8 \mathrm{~m}$; Phanerophyte $-8-30 \mathrm{~m}$; Megaphanerophyte - $>30 \mathrm{~m}$.

+ Fuzzy variables are those that are inherently categorical in nature, but which can occupy more than one category. 
Table 2. Indices of TD and FD used in this study. Equations and definitions were adapted from McGurran (2004) and Mouchet et al (2010).

\begin{tabular}{|c|c|c|c|}
\hline \multicolumn{2}{|c|}{ Name } & Formula & Description \\
\hline $\begin{array}{l}\text { Species } \\
\text { richness }\end{array}$ & $\mathrm{S}$ & $S=\sum S_{i}$ & Total number of species \\
\hline $\begin{array}{l}\text { Inverse } \\
\text { Simpson's } \\
\text { richness }\end{array}$ & $\mathrm{D}^{-1}$ & $D^{-1}=\frac{1}{\sum p_{i}^{2}}$ & $\begin{array}{l}\text { Inverse of summed } \\
\text { proportions of species } \\
\text { squared. }\end{array}$ \\
\hline $\begin{array}{l}\text { Simpson's } \\
\text { Evenness }\end{array}$ & $\mathrm{E}_{1 / \mathrm{D}}$ & $E_{1 / D}=\frac{(1 / D)}{S}$ & $\begin{array}{l}\text { Reciprocal of Simpson's D } \\
\text { divided by species } \\
\text { richness. }\end{array}$ \\
\hline $\begin{array}{l}\text { Functional } \\
\text { Richness }\end{array}$ & FRic & Quickhull Algorithm & $\begin{array}{l}\text { Convex Hull Volume: i.e. } \\
\text { the multivariate volume of } \\
\text { the minimum convex hull } \\
\text { that encloses all species in } \\
\text { functional space }\end{array}$ \\
\hline $\begin{array}{l}\text { Functional } \\
\text { Evenness }\end{array}$ & FEve & $F E v e=\frac{\sum_{i=1}^{S-1} \min \left(P E W_{i}, \frac{1}{S-1}\right)-\frac{1}{S-1}}{1-\frac{1}{S-1}}$ & $\begin{array}{l}\text { Sum of the branch lengths } \\
\text { of the minimum spanning } \\
\text { tree connecting species in } \\
\text { functional space. }\end{array}$ \\
\hline $\begin{array}{l}\text { Functional } \\
\text { Divergence }\end{array}$ & FDiv & $F D i v=\frac{\Delta d+\overline{d G}}{\Delta|d|+d G}$ & $\begin{array}{l}\text { Species deviance from the } \\
\text { mean distance to the centre } \\
\text { of gravity of trait space } \\
\text { weighted by relative } \\
\text { abundance. }\end{array}$ \\
\hline
\end{tabular}

$S=$ total species richness; $P_{i}$ is the total percent cover in each quadrat, $S_{i}=$ species $i ; 1 / \mathrm{D}$ is the reciprocal form of the Simpson's diversity index; PEW = partial weighted evenness; $i$ ' $=$ branch presence or absence row vector; $d G=$ mean distance to the centre of gravity; $\Delta d=$ sum of abundance-weighted deviances; $\Delta|d|=$ absolute abundance-weighted deviances from the centre of gravity; $\overline{d G}=$ centre of gravity. 
Table 3. GLS analyses with and without the inclusion of an overstory species:age interaction. Significance levels: . - marginally ns, $*_{-} \leq 0.05 ; * *-\leq 0.01 ; * * *-\leq 0.001$.

\begin{tabular}{|c|c|c|c|c|c|c|}
\hline \multirow[b]{2}{*}{ Variable } & \multicolumn{3}{|c|}{----- Models with species * age ----- } & \multicolumn{3}{|c|}{----- Models without species * age ---- } \\
\hline & Coefficient & St'd error & & Coefficient & St'd error & \\
\hline \multicolumn{7}{|c|}{ Species Richness } \\
\hline Intercept & 25.253 & 12.767 & . & 31.776 & 13.256 & * \\
\hline Species & 3.773 & 6.606 & ns & -8.861 & 3.641 & $*$ \\
\hline Age & -0.056 & 0.089 & ns & -0.166 & 0.080 & $*$ \\
\hline Closure & 0.207 & 0.116 & . & 0.244 & 0.122 & . \\
\hline Litter cover & 0.038 & 0.072 & ns & -0.004 & 0.073 & ns \\
\hline Litter depth & -0.144 & 2.262 & $\mathrm{~ns}$ & -1.149 & 2.755 & ns \\
\hline Organic $(\%)$ & -0.056 & 0.223 & ns & -0.065 & 0.238 & ns \\
\hline Species * Age & -0.343 & 0.153 & $*$ & - & - & - \\
\hline \multicolumn{7}{|c|}{ Species richness per quadrat } \\
\hline Intercept & 1.761 & 3.194 & ns & 5.514 & 3.786 & ns \\
\hline Species & 1.783 & 1.501 & $\mathrm{~ns}$ & -3.298 & 1.031 & $* *$ \\
\hline Age & 0.014 & 0.025 & ns & -0.065 & 0.021 & $* *$ \\
\hline Closure & 0.032 & 0.031 & ns & 0.060 & 0.039 & ns \\
\hline Litter cover & 0.021 & 0.015 & ns & 0.004 & 0.017 & ns \\
\hline Litter depth & 0.676 & 0.559 & ns & 0.112 & 0.651 & ns \\
\hline Organic (\%) & 0.067 & 0.051 & ns & 0.060 & 0.061 & ns \\
\hline Species * Age & -0.130 & 0.032 & $* * *$ & - & - & - \\
\hline \multicolumn{7}{|l|}{ Total cover } \\
\hline$\overline{\text { Intercept }}$ & 99.030 & 43.690 & * & 126.915 & 44.378 & ** \\
\hline Species & -0.873 & 20.570 & ns & -38.262 & 12.015 & ** \\
\hline Age & 0.198 & 0.347 & ns & -0.363 & 0.245 & ns \\
\hline Closure & -0.365 & 0.429 & ns & -0.171 & 0.446 & ns \\
\hline Litter cover & 0.0570 & 0.197 & ns & -0.066 & 0.201 & ns \\
\hline Litter depth & -1.976 & 7.541 & ns & -5.961 & 7.795 & ns \\
\hline Organic $(\%)$ & 0.270 & 0.690 & Ns & 0.175 & 0.734 & ns \\
\hline Species * Age & -0.963 & 0.442 & $*$ & - & - & - \\
\hline \multicolumn{7}{|c|}{ Species per percent cover } \\
\hline Intercept & 0.066 & 0.082 & ns & 0.053 & 0.083 & ns \\
\hline Species & -0.123 & 0.096 & ns & 0.157 & 0.046 & $* *$ \\
\hline Age & 0.000 & 0.001 & ns & -0.0001 & 0.001 & ns \\
\hline Closure & 0.001 & 0.001 & ns & 0.001 & 0.001 & ns \\
\hline Litter cover & -0.00001 & 0.001 & ns & 0.000 & 0.001 & ns \\
\hline Litter depth & 0.004 & 0.021 & ns & 0.005 & 0.021 & ns \\
\hline Organic (\%) & -0.001 & 0.001 & ns & -0.001 & 0.002 & ns \\
\hline Species * Age & 0.008 & 0.002 & $* *$ & - & - & - \\
\hline \multicolumn{7}{|c|}{ Simpson's diversity (D) } \\
\hline Intercept & 15.349 & 5.794 & $*$ & 20.481 & 6.085 & ** \\
\hline Species & 1.795 & 2.833 & ns & -4.747 & 1.726 & $*$ \\
\hline Age & -0.036 & 0.050 & ns & -0.155 & 0.031 & $* * *$ \\
\hline Closure & 0.066 & 0.061 & ns & 0.105 & 0.067 & $\mathrm{~ns}$ \\
\hline Litter cover & 0.010 & 0.024 & ns & -0.007 & 0.024 & ns \\
\hline Litter depth & -0.476 & 0.911 & ns & -1.146 & 0.942 & ns \\
\hline Organic (\%) & -0.033 & 0.085 & ns & -0.048 & 0.091 & $\mathrm{~ns}$ \\
\hline Species * Age & -0.161 & 0.059 & $*$ & - & - & - \\
\hline
\end{tabular}


Table 3 (continued)

\begin{tabular}{|c|c|c|c|c|c|c|}
\hline \multirow[b]{2}{*}{ Variable } & \multicolumn{3}{|c|}{----- Models with species * age ----- } & \multicolumn{3}{|c|}{----- Models without species * age ---- } \\
\hline & Coefficient & St'd error & & Coefficient & St'd error & \\
\hline \multicolumn{7}{|c|}{ Simpson's Evenness } \\
\hline Intercept & 0.491 & 0.097 & $* * *$ & 0.514 & 0.094 & $* * *$ \\
\hline Species & -0.002 & 0.047 & ns & -0.039 & 0.025 & ns \\
\hline Age & -0.001 & 0.001 & $\mathrm{~ns}$ & -0.002 & 0.001 & $*$ \\
\hline Closure & 0.0003 & 0.001 & ns & 0.0004 & 0.001 & ns \\
\hline Litter cover & 0.0001 & 0.001 & $\mathrm{~ns}$ & 0.00003 & 0.000 & $\mathrm{~ns}$ \\
\hline Litter depth & 0.064 & 0.019 & ** & 0.060 & 0.018 & $* *$ \\
\hline Organic $(\%)$ & -0.001 & 0.002 & ns & -0.001 & 0.002 & ns \\
\hline Species * Age & -0.001 & 0.001 & ns & - & - & - \\
\hline \multicolumn{7}{|l|}{ FRic } \\
\hline$\overline{\text { Intercept }}$ & 0.00069 & 0.00177 & ns & 0.00061 & 0.00169 & ns \\
\hline Species & -0.00030 & 0.00089 & ns & -0.00015 & 0.00046 & $\mathrm{~ns}$ \\
\hline Age & 0.00001 & 0.00001 & ns & 0.00001 & 0.00001 & ns \\
\hline Closure & 0.00002 & 0.00002 & $\mathrm{~ns}$ & 0.00002 & 0.00002 & ns \\
\hline Litter cover & -0.00001 & 0.00001 & ns & -0.00001 & 0.00001 & ns \\
\hline Litter depth & -0.00008 & 0.00036 & ns & -0.00007 & 0.00034 & ns \\
\hline Organic (\%) & -0.00002 & 0.00003 & ns & -0.00002 & 0.00003 & ns \\
\hline Species * Age & 0.00000 & 0.00002 & ns & - & - & - \\
\hline \multicolumn{7}{|l|}{ FEve } \\
\hline Intercept & 0.624 & 0.199 & ** & 0.585 & 0.190 & ** \\
\hline Species & -0.007 & 0.101 & ns & 0.063 & 0.052 & ns \\
\hline Age & 0.000 & 0.001 & ns & 0.001 & 0.001 & ns \\
\hline Closure & -0.003 & 0.002 & ns & -0.003 & 0.002 & ns \\
\hline Litter cover & -0.001 & 0.001 & ns & -0.001 & 0.001 & ns \\
\hline Litter depth & -0.049 & 0.040 & $\mathrm{~ns}$ & -0.042 & 0.039 & $\mathrm{~ns}$ \\
\hline Organic (\%) & 0.005 & 0.003 & ns & 0.004 & 0.003 & ns \\
\hline Species * Age & 0.002 & 0.002 & $\mathrm{~ns}$ & - & - & - \\
\hline \multicolumn{7}{|l|}{$\underline{\text { FDiv }}$} \\
\hline$\overline{\text { Intercept }}$ & 0.413 & 0.154 & $*$ & 0.498 & 0.157 & $* *$ \\
\hline Species & 0.067 & 0.076 & ns & -0.082 & 0.043 & . \\
\hline Age & 0.000 & 0.001 & $\mathrm{~ns}$ & -0.002 & 0.001 & . \\
\hline Closure & -0.003 & 0.001 & . & -0.002 & 0.001 & ns \\
\hline Litter cover & 0.004 & 0.001 & $* * *$ & 0.003 & 0.001 & $* *$ \\
\hline Litter depth & 0.056 & 0.030 & . & 0.045 & 0.032 & ns \\
\hline Organic (\%) & 0.001 & 0.003 & ns & 0.001 & 0.003 & $\mathrm{~ns}$ \\
\hline Species * Age & -0.004 & 0.002 & $*$ & - & - & - \\
\hline
\end{tabular}


Table 4. Pearson correlation coefficients and associated significance levels calculated between all measures of TD and FD. Significance levels are as shown in Table 3.

\begin{tabular}{|c|c|c|c|c|c|c|c|c|c|c|}
\hline \multirow[b]{2}{*}{ Red Pine } & $\begin{array}{l}\text { Species } \\
\text { richness }\end{array}$ & \multicolumn{2}{|c|}{$\begin{array}{c}\text { Richness } \\
\text { per } \\
\text { quadrat }\end{array}$} & \multicolumn{2}{|c|}{$\begin{array}{c}\text { Richness } \\
\text { per percent }\end{array}$} & $\begin{array}{c}\text { Simpson's } \\
\text { D }\end{array}$ & \multirow[t]{2}{*}{$\begin{array}{c}\text { Simpson's } \\
\text { evenness }\end{array}$} & \multirow[t]{2}{*}{$\begin{array}{c}\text { Cover per } \\
\text { quadrat }\end{array}$} & \multirow[t]{2}{*}{ FRic } & \multirow[t]{2}{*}{ FDiv } \\
\hline & & & & & & & & & & \\
\hline \multicolumn{11}{|l|}{ Species richness } \\
\hline Richness per quadrat & $0.61 * *$ & & & & & & & & & \\
\hline Richness per percent & $-0.60 * *$ & -0.80 & $* * *$ & & & & & & & \\
\hline Simpson's D & $0.86 * * *$ & 0.70 & $* *$ & -0.61 & $* *$ & & & & & \\
\hline Simpson's evenness & -0.04 & 0.30 & & 0.02 & & 0.30 & & & & \\
\hline Cover per quadrat & $0.73 * * *$ & 0.67 & $* * *$ & -0.77 & $* * *$ & $0.60 * *$ & -0.08 & & & \\
\hline FRic & 0.20 & -0.30 & & 0.13 & & 0.04 & -0.24 & -0.13 & & \\
\hline FDiv & 0.43 . & 0.39 & & -0.23 & & $0.54 *$ & 0.17 & 0.34 & -0.43 & \\
\hline FEve & -0.03 & -0.04 & & 0.22 & & -0.02 & -0.03 & -0.04 & 0.14 & -0.35 \\
\hline \multicolumn{11}{|l|}{ Jack Pine } \\
\hline \multicolumn{11}{|l|}{ Species richness } \\
\hline Richness per quadrat & $0.80 * * *$ & & & & & & & & & \\
\hline Richness per percent & 0.43 & 0.22 & & & & & & & & \\
\hline Simpson's D & $0.88 * * *$ & 0.74 & $* * *$ & 0.42 & & & & & & \\
\hline Simpson's evenness & 0.19 & 0.27 & & 0.06 & & $0.50 *$ & & & & \\
\hline Cover per quadrat & -0.25 & 0.01 & & -0.85 & $* * *$ & -0.25 & -0.08 & & & \\
\hline FRic & 0.27 & 0.29 & & -0.09 & & 0.21 & -0.28 & 0.11 & & \\
\hline FDiv & 0.15 & 0.32 & & 0.24 & & 0.32 & $0.66 * *$ & -0.20 & -0.55 . & \\
\hline FEve & -0.30 & -0.28 & & -0.43 & . & -0.38 & -0.01 & 0.22 & -0.12 & -0.18 \\
\hline
\end{tabular}


Table 5. Summary results for RLQ analysis compared to separate ordinations of environment, species, and traits. RLQ seeks a linear combination of traits (species scores) and a linear combination of environmental variables (sample scores) that maximizes the covariance measured through the species abundance (L) table. Inertia (RLQ) refers to the variance in species and environmental scores captures by the RLQ analysis, while max (PCA) refers to the same term for the separate analyses. Their ratio measures the cumulative proportion of PCA variance explained by the corresponding table of scores in RLQ. Correlation (RLQ) refers to the correlation of traits and environment mediated by species scores (L).

\begin{tabular}{|c|c|c|c|}
\hline \multicolumn{4}{|c|}{ Inertia \& coinertia RLQ:Environment } \\
\hline Axes & Inertia (RLQ) & $\operatorname{Max}(\mathrm{PCA})$ & Ratio \\
\hline 1 & 2.225 & 3.384 & 0.657 \\
\hline $1+2$ & 4.970 & 5.927 & 0.839 \\
\hline \multicolumn{4}{|c|}{ Inertia \& coinertia: RLQ:Traits } \\
\hline Axes & Inertia (RLQ) & $\operatorname{Max}(\mathrm{PCA})$ & Ratio \\
\hline 1 & 5.801 & 6.316 & 0.919 \\
\hline $1+2$ & 8.198 & 9.597 & 0.854 \\
\hline \multicolumn{4}{|c|}{ Correlation RLQ:Species } \\
\hline Axes & Correlation (RLQ) & $\operatorname{Max}(\mathrm{CA})$ & Ratio \\
\hline 1 & 0.346 & 0.747 & 0.463 \\
\hline 2 & 0.222 & 0.621 & 0.358 \\
\hline
\end{tabular}

Eigenvalue decomposition of RLQ

\begin{tabular}{ccc} 
Axes & Eigenvalue & $\begin{array}{c}\text { Covariance (traits- } \\
\text { Environment }\end{array}$ \\
\hline 1 & 1.543 & 1.242 \\
2 & 0.325 & 0.571 \\
\hline
\end{tabular}


Figure 1. Layout of permanent sample plot and distribution of vegetation sampling transects and anciliary microplots.

Figure 2. Taxonomic diversity (TD) indices analysed in this study. Jack pine stands are indicated in open circles, and red pine by grey triangles. A 105-year-old fire-origin red pine stand is indicated with an asterisk.

Figure 3. Functional Diversity (FD) indices used in this study. Symbol interpretations are as in Figure 2.

Figure 4. A) Percent litter cover versus FDiv, and B) average vegetation cover (per quadrat) versus number of species per percent cover. The asymptotic negative exponential equation with pseudo-R-squared is shown at the head of graph B. Symbol interpretations are as in Figure 2.

Figure 5. Results of RLQ analysis. In R (Environment) jack pine (circles) and red pine (triangles) are coloured by stand age: clear $\leq 30 \mathrm{yr}$; light grey $>30-50 \mathrm{yr}$.; dark grey $>50 \mathrm{yr}$. Environmental symbols: Density - overstory stem density $\left(\mathrm{ha}^{-1}\right)$, Age - stand age in years, $\mathrm{Mgd}$ - managed, Nat - natural (fire origin), Closure.pct - canopy closure, LC - litter cover, LD - litter depth, WD - woody debris cover, and JP and RP are jack pine and red pine centroids, respectively. Trait symbols are as follows: Geo - Geophyte H_Cryp - hemicryptophyte, Pleuro - pleurocarpus mosses, Acroc - acrocarpus mosses, Cham - chamaephytes, Mic_P - microphanerophyte, Phan - phanerophyte, Meg_P - mega-phanerophyte, Annual - annual plant, Biann - biannual, Peren - perennial, Everg - evergreen, Decid - deciduous, Flowerssn - season of flowering, SeedL - seed length, maxHt - max height $(\mathrm{cm})$; Vegetative reproduction (Colsprout sprouting, Creepstem - horizonatal stems, Frag -fragments (mostly mosses), Layer layering(trees), Rhizome - rhizomes, Rhizoid - rhizoids, Stump - stump sprout, Fibrous fibrous roots), Shade - relative shade tolerance; Dispersal: Insect, Bird, Water, Expl - explosive, 
Endzoo - endozoochory, Unassist - unassisted, Human - human-assisted, Wind, Exozoo exozoochory (e.g. burrs). Eight letter plant acronyms are recorded in Table S1?. For Q (traits) and species (L), symbols have been jittered to reduce overlap, and only the most influential points on the axes are shown.

Figure 6. Results of fourth corner analysis. Positive correlations are in dark grey, negative correlations in white, and no significant correlations in light grey. Symbols for traits and environmental variables are as in Figure 4. Significance levels are as shown in Table 3. 


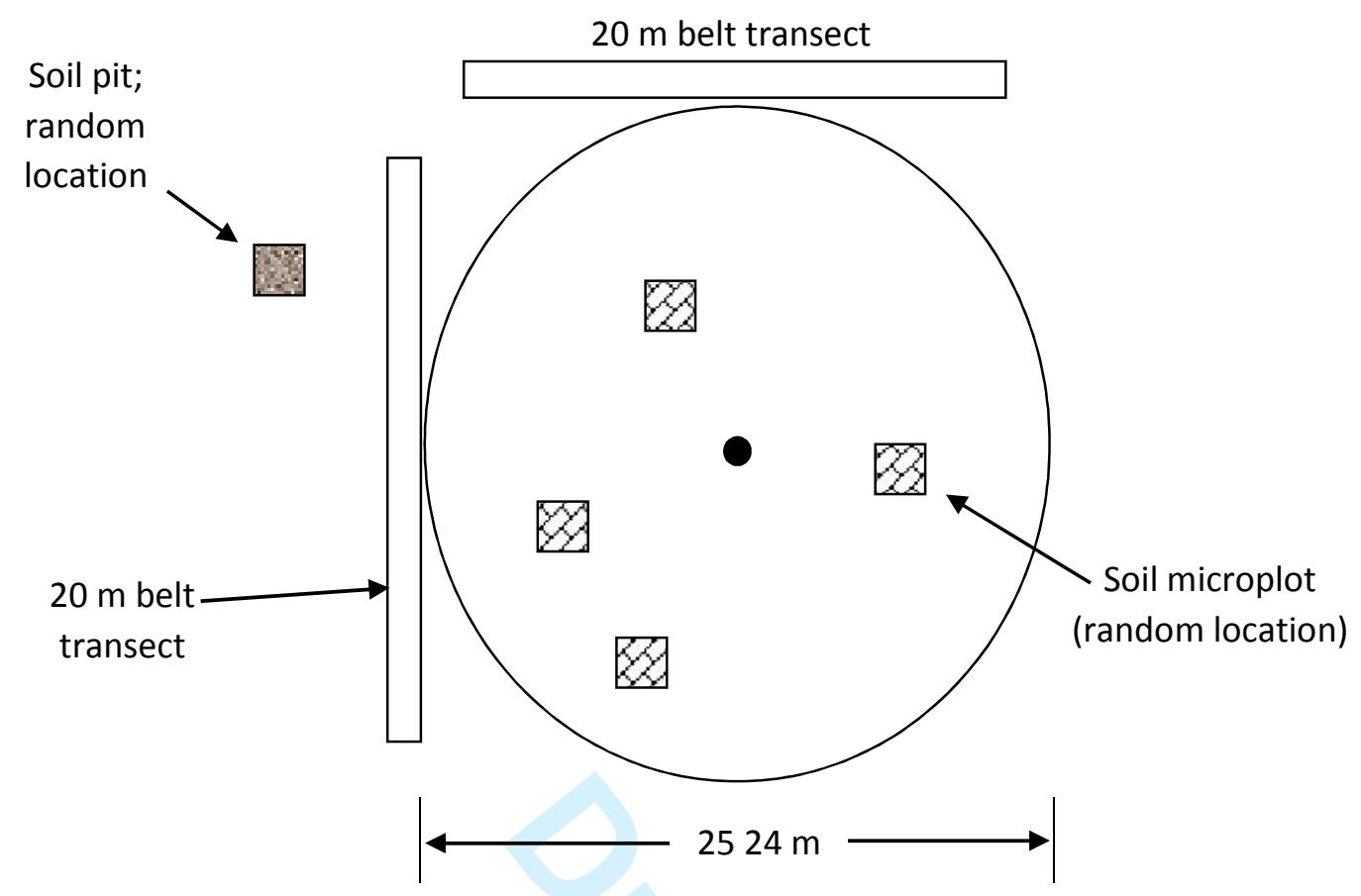



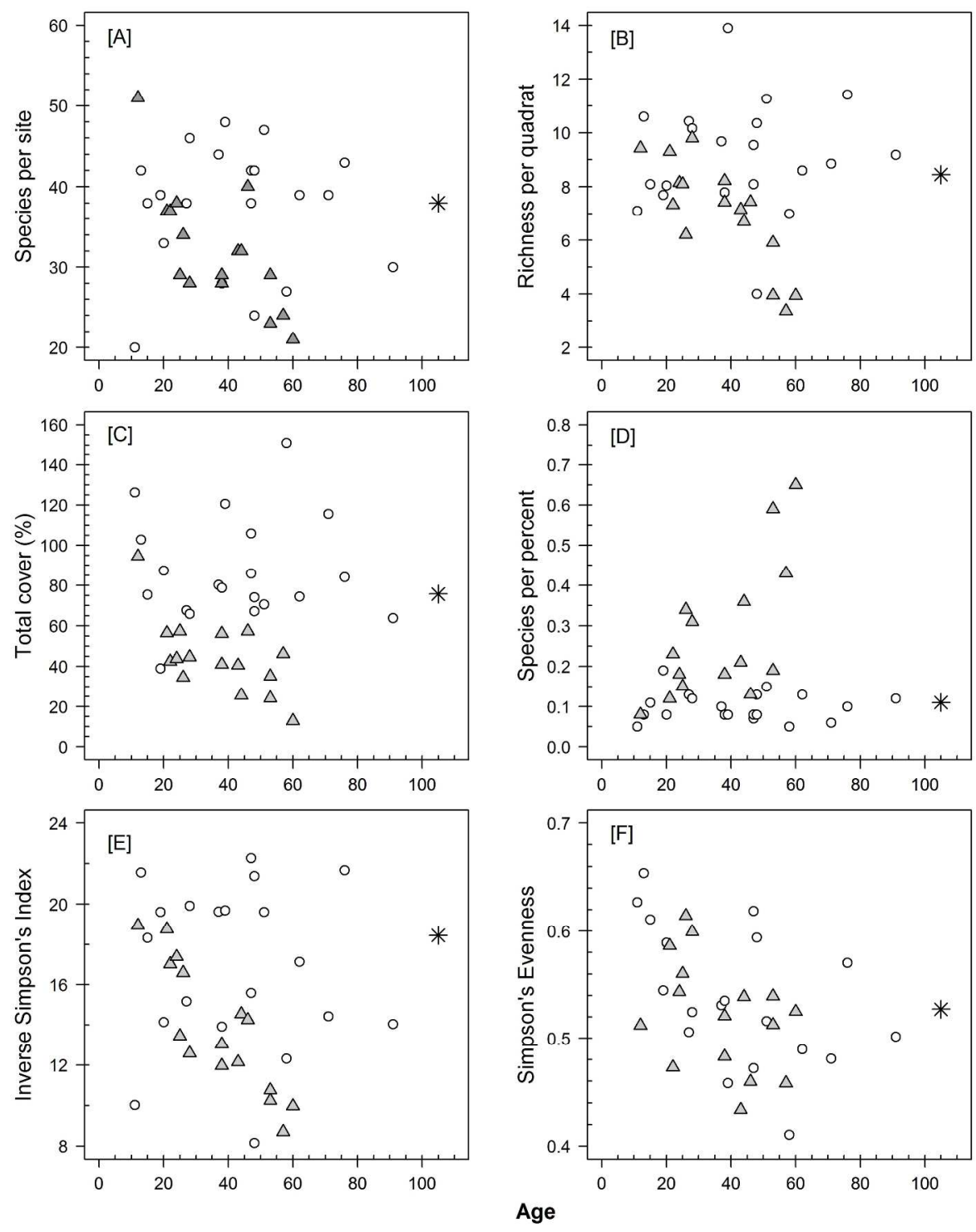

$254 \times 317 \mathrm{~mm}(300 \times 300 \mathrm{DPI})$ 

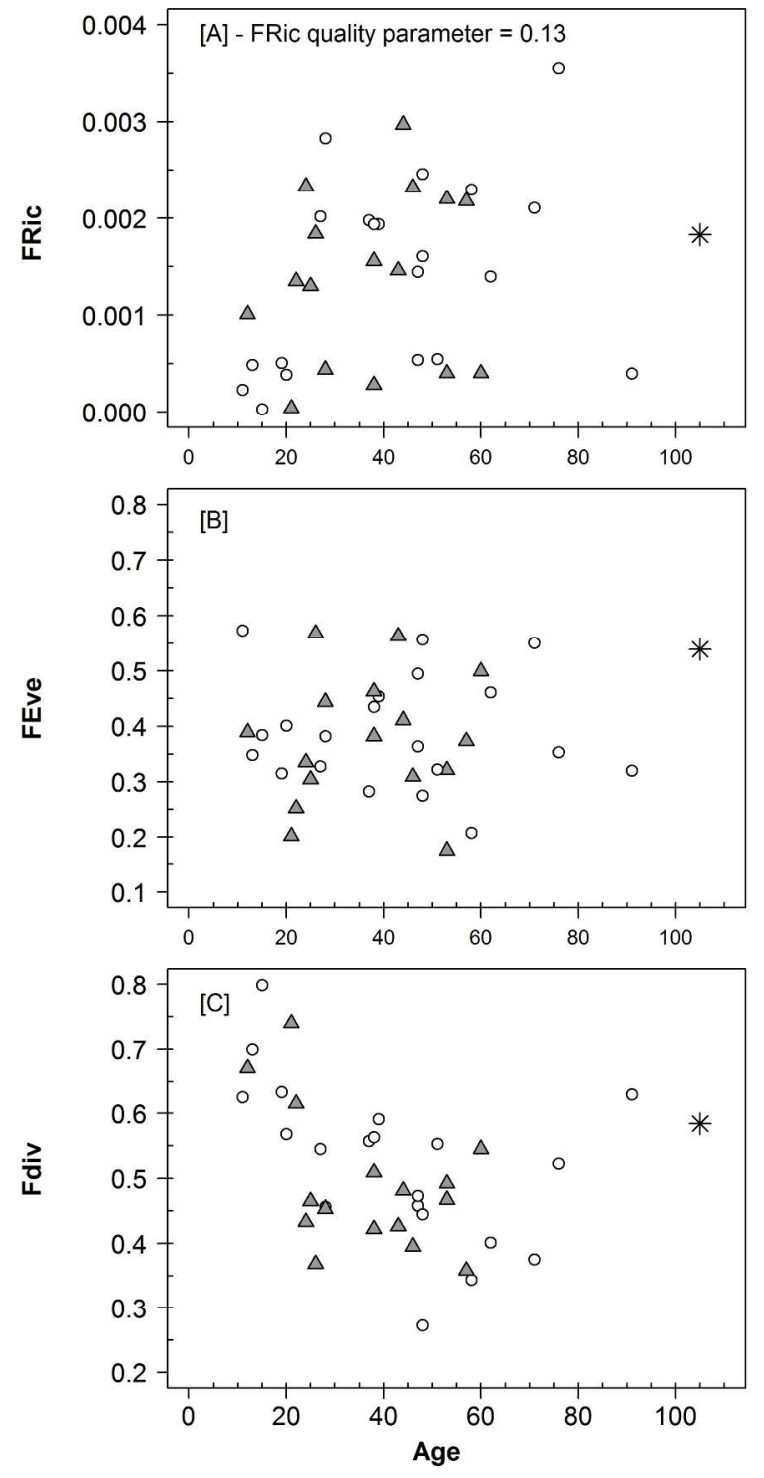

$254 \times 508 \mathrm{~mm}(300 \times 300$ DPI $)$ 

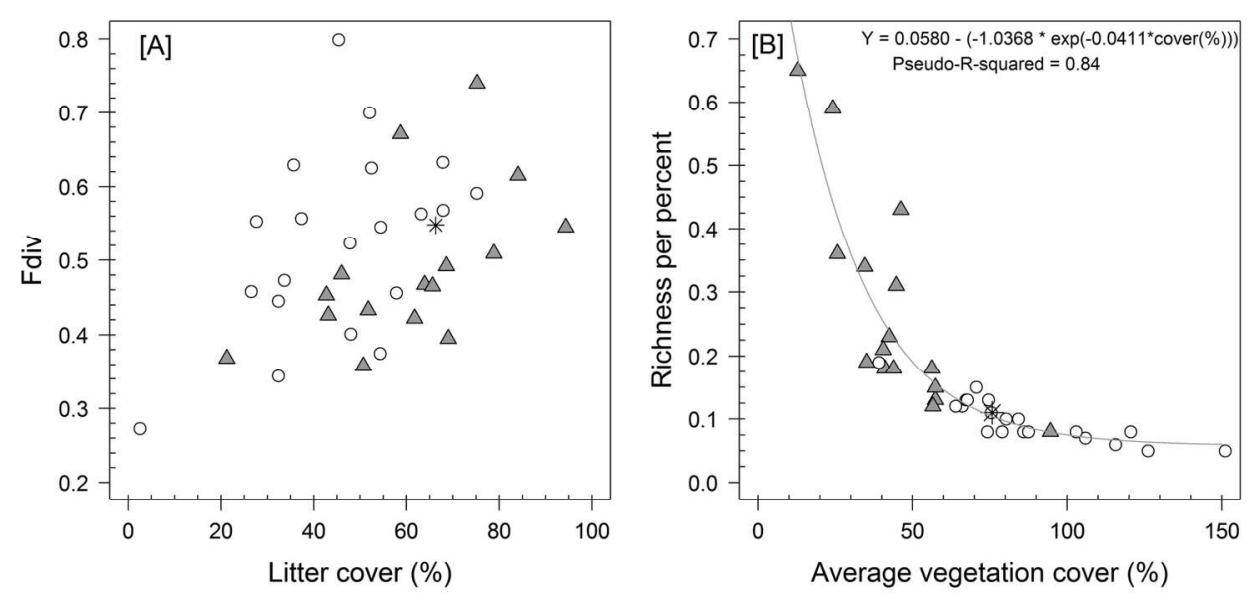

$152 \times 76 \mathrm{~mm}(300 \times 300 \mathrm{DPI})$ 

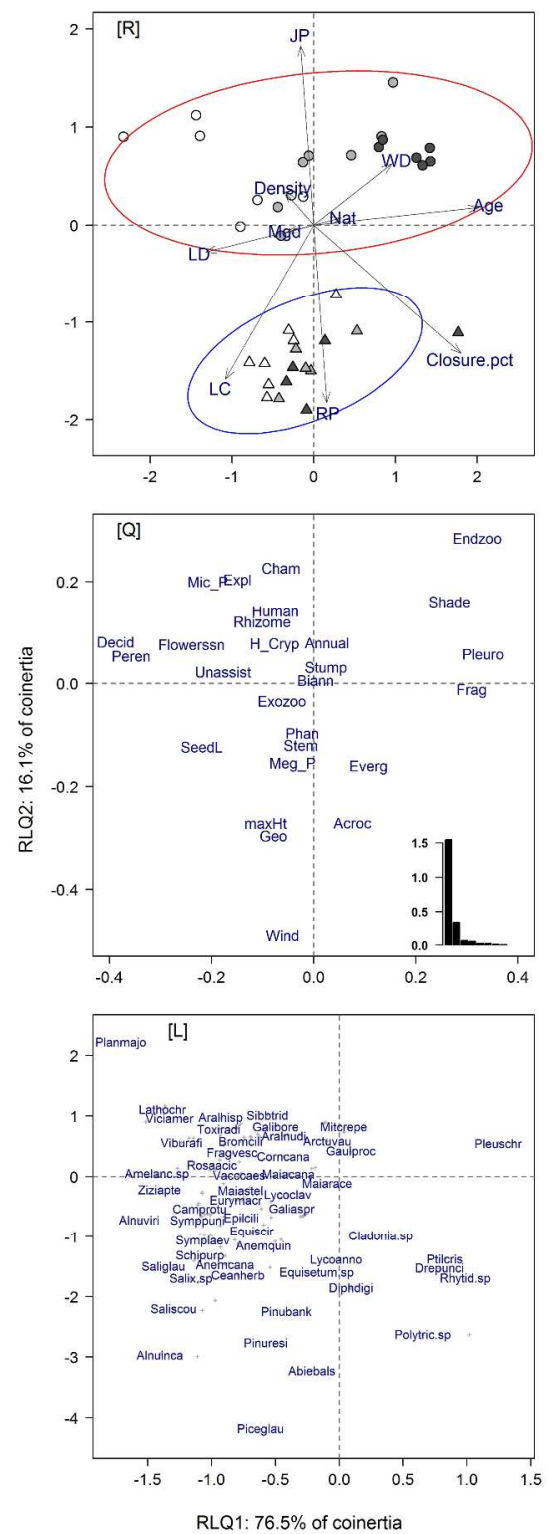

$355 \times 995 \mathrm{~mm}(300 \times 300$ DPI $)$ 


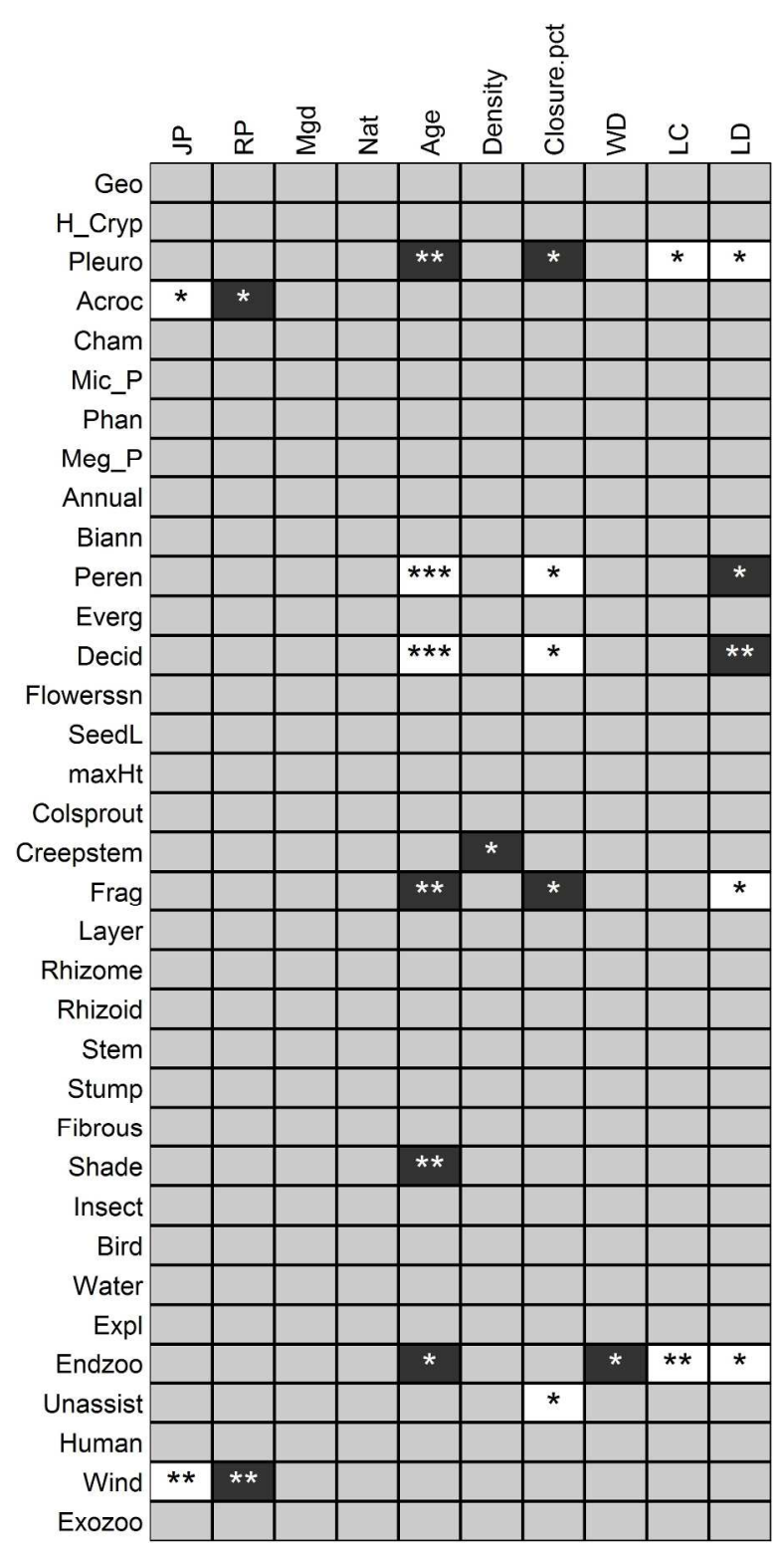

$254 \times 508 \mathrm{~mm}(300 \times 300$ DPI $)$ 